\title{
IPad in Elementary School Math Learning Setting
}

\author{
http://dx.doi.org/10.3991/ijet.v11i02.5053 \\ Ibtesam Fares Al-Mashaqbeh \\ Al al-Bayt University (AABU), Mafraq, Jordan
}

\begin{abstract}
The aim of this study was to investigate the difference between the effect of using traditional teaching instruction and using iPad to teach math for first grade students. This study was conducted in one private elementary school in Jordan. The study used a quasi-experimental control design. Students have access to a few math software and websites that was downloaded to improve their math skills. Every student in the experimental group will have a personal iPad to be used during their math class period. Both groups will be given a pre-test and a post-test to measure their achievements in math. The motive for this research was encouraging teachers and students to use iPad for educational purpose instead of use it most of the time for fun and games. it a helpful tool to be used as part of the mathematic learning process. Also, there are many software and internet sites that can be downloading in the iPadt to improve students' math skills.
\end{abstract}

Index Terms - math, tablet, e-textbook, e-learning, education, educational technology.

\section{INTRODUCTION}

Decision makers in education see technology as a perfect solution to improve students learning performance and increase their motivation for learning [1]. There are increase in the internet access in the U.S. schools, it increased from $3 \%$ in 1994 to $94 \%$ in 2005 [2]. The first consumers received iPads with $\mathrm{WiFi}$ and 3 Gon 30 April 2010 in the USA [3].

iPad applications are the most advanced technology that carries out the education requirements by focusing on students' needs and higher education expectations [4]. This devise have all the PC's computers applications but it have a special tools that PC devices does not have which it is the special pen to write on screen to support class activities [5]. The iPads is a touch screen device, which designed in a suitable format that made it easily to be used by young students. It motivates students during their learning process by encouraging them to download interactive applications. They can access valuable resources such as a dictionary and useful websites. It has many tools to be used to support education settings such as audio and video recorders, email, and camera [6]. It supports more than a three thousand computer applications that increase the benefits of using it in teaching [7]. Using iPads as a learning tool should support students' needs and increase student's engagements. It allows students to access their curriculum on ways that enhance learning. The main challenge teacher's face during the process of using the iPad in school is getting students and parents to view this tool as a learning device not as a game device [8].

There are many benefits of using iPad such as: students can be in charge of their learning, replace textbook by using e-textbook, students can submit their homework and assignment, and improving their math skills by download- ing math activities. It also, can fill teachers' shortage in some schools, help students with disabilities, and improve students' engagements [9].

There are many applications that available on iPhone, and iPad. These applications are suitable for mobile learning for k-12 students. It should impact student learning process and motivate them to learn in an active way [10]. It helps improving students writing skills in many ways such as: using internet resources, online text editor, and exchange idea. It also, support collaborative work environment as a group work [11]. There are many applications that can be downloaded and used by teachers in different subjects such as: Productivity Tools (wordprocessing), Teaching Tools ( presentation tools), Notes Tools (Draw Free and iPocketDraw), Communication Tools (Facebook), Drives (Dropbox), Blogging Tools (Blogsy and Wordpress), and Content Accessing Tools

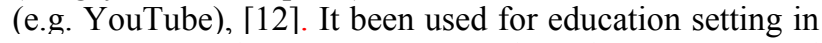
many ways such as: Internet search, video creation and editing, take notes and store teacher's lecture material, participate in discussion forums, and use Class blogs. It also can be used for specific topics such as art by allowing students to draw and paint, in music class by allows students to learn about variety of musical instruments [6].

There are wide ranges of science applications can be download on iPad that support science learning process. In chemistry there are many iPad applications such as: A Visual Exploration, Molecules, Periodic Table of the Elements, Ball \& Stick, NIOSH Chemical Hazards, and Self Assembly. On biology iPads applications such as: On-Screen DNA Model, 3D Brain, 3D Cell, Monster Anatomy HD, Skeletal HD, Pocket Heart, and GeneIndexHD. Students can use their own iPad to find many software and websites that help them find specific information such as: Science Glossary, Wolfram Alpha, PLoS Reader, Math Ref, and Kindle. Also they can use many tools to learn learning different topics and new ideas for example: iLab: Timer HD, Seismograph, Temp-Convert Universal, Unit Conversion Pro, National Geographic World Atlas, and Space-Time for iPad [13].

The use of iPad-computer in mathematic class has two advantages: First, Mathematics classes become more enjoyable for students by using different visuals and animations to practice math. Second, the new math concepts and topics become more understandable and clear [14]. "The best practice in teaching of using the iPad is to choose the applications in a way that help approach teaching in a supportive and easy way "[15]. It allowed teachers to design teaching process in a way that personalized learning activities to meet students learning needs [16]. For example, First grade math curriculum required to learn the addition and subtraction within twenty. Students can use many iPad applications to support their understanding of this topic such as: Flashcard++,Fur.lay, Replay Note apps [17]. 


\section{A. Bloom Taxonomy and math}

A Bloom Taxonomy is tool that was developed by Benjamin S. Bloom (1913-1999) to describe the best practice in classroom setting and activities [181. The new revision of the Bloom Taxonomy (Fig. 1) designed in a way that used verbs rather than nouns for each of the chart taxonomy categories. The chart categories were arranged in an increasing order, from Lower Order Thinking Skills (LOTS) to Higher Order Thinking Skills (HOTS) [19].

It is often used in mathematic to create exams and activities in a way that improve students' skills. In math content this is an example of the Bloom Taxonomy levels: Knowledge (retention of terminology, facts, methodologies, principles), Comprehension (grasping of meaning, extrapolation, interpretation of facts, making comparisons),Application (problem solving, use of new information in different way), Analysis (making inferences and supporting them with evidence, use patterns), Synthesis (relations, prediction, generalization, creation), and Evaluation ( judgments of validity, make conclusions, discrimination [20]. Using Bloom Taxonomy to teach math well contribute to students learning developments. It could be used to help teacher's select special software (as shown on table 1) as a part of students iPads to improve students math skills and motivate them [21].

\section{RELATED WORK}

[22] examined the use of iPad PCs with specialized pens in biomedicine subjects. Students indicated that they felt using this tool was more interesting, enhanced their understanding of the content, and helped them keep up with the lecturer. [23] studied the attitude of elementary school teacher, principal, and students' parents toward the influence of the use of iPod touch on students learning and engagement. The finding revealed that the use of this device was consistent with pedagogical practices. It also support self-learning, peer mentoring, students engagement, and students communication out of the school

[24] examined the ways teachers, students, principals, parents, educators, and other decision makers in education can support the use of the iPads for learning in more effective ways. A study was conducted in Quebec, Canada. The participants of the study were an 18 elementary and high schools. The survey was distributed to 302 teachers and 6057 students in the selected schools in the province of, Canada. The result of the study shows that using iPad is not a smooth transition but it consider as a necessary risk for schools. It could be a challenge for teachers to integrate the use of iPad in education setting, unless the governments and the education decision makers provide teachers with suitable training programs

[25] investigated how the fourth grade teachers integrated iPads as a learning tool into their literacy instruction. iPads was used for a three-week period. During this period a selected applications that provided unique approaches to helping the students meet their literacy learning goals was download on students' iPads. A lesson was developed as a presentation saved in the iPad. The result of the study supported the use of this device in literacy classrooms. This study provides a foundation for integration of iPads as a tool for teaching process

[26] investigated the ways that students use iPad in Bond University, Australia. Students used Blackboard Mobile that work on devices as the iPad, iPod and iPhone

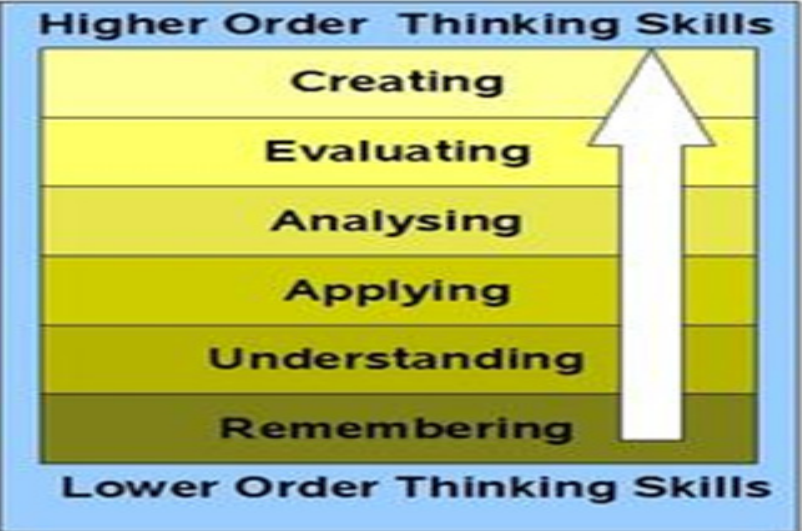

Figure 1. New Revision of the Bloom Taxonomy

TABLE I.

BLOOM TAXONOMY AND MATH SOFTWARE

\begin{tabular}{|c|c|c|}
\hline Creating & $\begin{array}{l}\text { Create } \\
\text { Predict } \\
\text { Image }\end{array}$ & \\
\hline Evaluating & $\begin{array}{l}\text { Analysis of elements, } \\
\text { Relationships, } \\
\text { organizatial principles. }\end{array}$ & ha ris \\
\hline Applying & $\begin{array}{l}\text { Examine } \\
\text { Compare } \\
\text { Explain }\end{array}$ & Mindblowing \\
\hline Understanding & $\begin{array}{l}\text { Discuss } \\
\text { Visualize } \\
\text { Explain }\end{array}$ & \\
\hline Remembering & $\begin{array}{l}\text { Tell } \\
\text { List } \\
\text { Write }\end{array}$ & Splash Math \\
\hline
\end{tabular}

to access their subject sites, participate in discussion forums, access to the electronic version of the assigned textbook, and submit assignments. The result of the study showed that using this device was like have all the learning tools in one place. They appreciated having their subjects' e-textbook on their own device which made it cheaper than purchasing the paper book

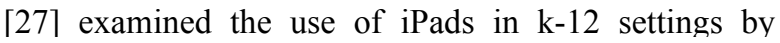
teachers and their students to create educational tutorials, recorded video, recorded interviews, and plan students' homework. They used the iPad to create development plan and assessment tools. Teachers noticed that students were very motivated during their lessons when they used their iPads

[28] examined the effect of using iPad to teach kindergarten students. Students were tested on their literacy skills as a pretest and a post test. A result of this study indicated that the use of iPad by students improved their performance, students who used the device found that it was engaging, interactive, and it also gave students immediate feedback 
[29] states that there are global changes in teaching practice and tools been used to support improving students reading and writing skills. This study used iPad as a learning tool and saved the digital text to be used in the literacy classroom for low-socioeconomic and ethnically diverse students. Many lessons were designed by using: hyperlinks, multimedia, challenge students, creating, and sharing ideas. The study found that using iPad as a teaching tool was a helpful and support motivated students to learn. It includes students' were communicated together from home, critical media literacy, collaborative and creative digital text production, and search information as a global communities

[30] conducted to compare between using regular teaching (lecturer method, PowerPoint slides, and chalkboard) and using tablets PC. The result found that students who used tablets PC performed better in their exam than the other group. Students added that this device help understand topic new terms and content

\section{THE STUDY}

\section{A. The important of the study}

The new era of education move toward the use of iPad as a teaching and learning tool. It supports different areas such as math, science, geography, and language. There many educational software, websites, games, and other materials that can be helpful for students to improve their math skills. So, this device could supports education process in many ways:

- improve collaborative learning

- personalize learning experiences

- enhance deep learning

- switch learning contexts from formal to informal setting

- offers security, backup, restore of data

- transform teaching practice.

- motivate students by having active learning setting.

- enable a wider range of math activities.

- offer quick access to web application.

- enable reinforcement

- support creativity

- support research and critical thinking

\section{B. Purpose of the study}

The purpose of this study was to investigate the difference between the effect of using traditional teaching instruction and using iPad to teach math for first grade students. For this study, a pre-test was conducted before starting the experiment and a post-test assessment was conducted following multiple activities that used iPad device. Using this device in math teaching consider as moving from the traditional math teaching to providing student with access to digital resources and positive learning engagement. The specific questions answered by this study were:

- Is there a significant difference between the experimintal group students (first grade students students) achievments who used iPad in their math subject?

- Is there a significant difference between the achievments of the expermintal group (on first grade students) who used iPad in their math subject and the control group who used the traditional teaching method?

\section{Methodology}

\section{A. Sample}

The present study was conducted at one private elementary school in irbid-Jordan (Al-Ahed) that using iPad as a learning tool for first grade students. The study used a quasi-experimental control. The sample of the study was eighty first grade students, were divided to two groups of forty. One group was the regular group (R-group) who was taught math by a traditional teaching way and the second group that was the experimental group (E-group) using iPad device to study and practice math topics.

\section{B. Research Instruments}

\section{1) iPad applications.}

Prior to the beginning of the semester each student in the E-group was issued a personal iPad to be use during the class period. With the support of the computer lab assistant, a number of selected computer applications installed on each student iPad such as: math games, test, math lessons, school website, math websites, math textbook, and yahoo emails . After preparing students' devices with the selected software, teachers chose a few websites that could be helpful for first grade math students. Students were given instruction for connecting their device to the Internet and use the chosen websites. Students used it during their math class period as teacher planned for each class time. Students were free to move about the room to view each other's work and activities. They used the iPads until the end of the semester which was three months period.

\section{2) Achievement Test}

The researchers design test elements to measure students' achievement on math. The test was design with the help of the first grade math teachers and the researcher. It majored students math achievements on the first semester topics that included on teachers guide.

\section{Procedure Research Instruments}

This study considered as a semi-empirical of the type pretest-posttest design given to two equivalent groups. Rgroup taught by a traditional teaching method and E-group was taught by using the iPad device. The only independent variable in this study was the teaching method which has two levels:

- Teaching Method using the iPad

- Traditional teaching Method

The procedures of the study were designed to answer the research question as shown on (Fig. 2):

- The students were assigned randomly to two groups

- Teachers with the help of the computer lab assistant prepare students iPads by having access to few math software and websites and e-textbook.

- The personal iPad was handed to each student

- Teachers trained student about the use of the device.

- A math pre-test was given to the two groups

- The period of the study was one semester 
- At the end of the semester a post-test was given to the two groups to major students' math achievements.

- The researcher made few visits during the semester and talk to teachers and students and write some comments

- The researchers use a suitable statistic method to analyze the data.

\section{RESUlTS AND DisCUSSION}

The main goal of this study was to examine the difference between the effect of using traditional teaching instruction and using iPad to teach math for first grade students.

The researcher examines the equivalents of the two groups (R-group and E-group) by applying a math pretest. The result of this test shows that the two groups were equivalents as shown on Table II.

The result related to the first research question "Is there a significant difference between the experimintal group students (first grade students students) achievments who used iPad in their math subject" was showen on Table III. It revealed that the Mean for the post test result was 92.62 compare with the pre test result mean which was 42.33 . This result showes that the differents between the two means was 50.29, it indicated that the use of iPad on teaching math was a usefull method. There was a significant differents between the experimental group students pre-test and post-test scores in the side of the post test scores.

The result related to the second research question"Is there a significant difference between the achievments of the expermintal group (on first grade students) who used iPad in their math subject and the control group who used the traditional teaching method" was as shown on Table IV. It revealed that the experiminatl group who used the iPad applications on their math subject has 92.62 mean compare to the reguler group who used the reguler way of math teaching method which was 88.5. This indicated a significant differents between the two groups in the side of the experimintal group.

[31] indicated that using netbook device offers many advantages for the education settings. It is offer a digital access for the class materials, more digital activities, students more interactive during the class period and easy to carry inside and outside of the school.it is an inexpensive device that makes it more suitable for students. This results match with other study result that related to the positive effect of iPads on students' performance such as: [28], [32] and [33].

From my experience, using iPad applications for math subject help personalize learning. Each student has different learning style for that, their teachers can download many multimedia applications that help personalize learning such as: using video, sound, documents, and pictures. Technology in education is a suitable method that supports students to learn new math concepts and problem solving method. This study found that iPad as a math teaching method can effect positively on students achievements compare to the regular way of teaching. By looking at the result of this study, using IPad to learn math concepts and practice problem solving skills is recommended. Student by this method will have a chance to read, write, watch, and listen and be creative

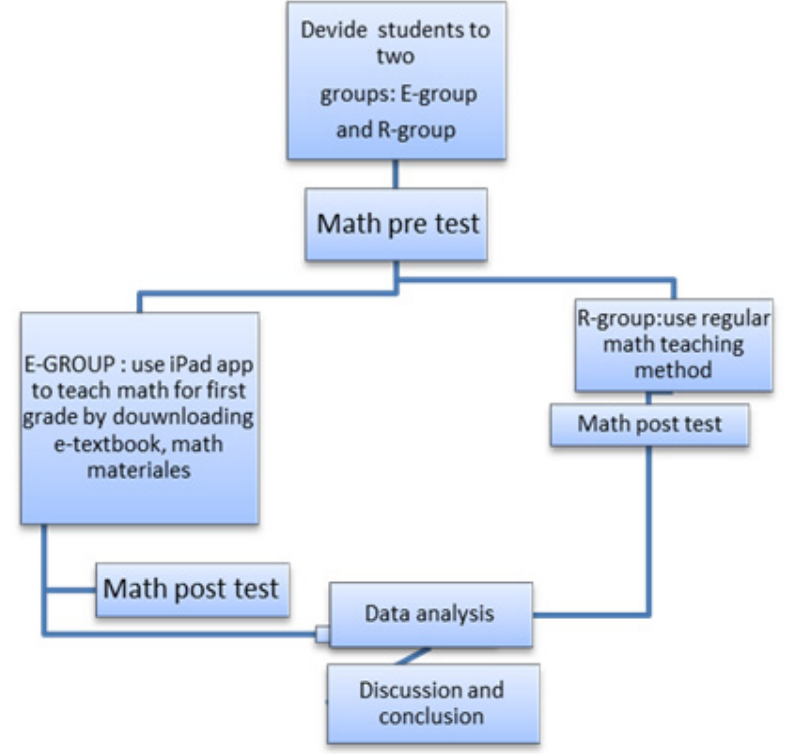

Figure 2. Research flowchart

TABLE II.

PRE-TEST SCORE FOR R-GROUP AND E-GROUP

\begin{tabular}{|l|c|c|c|c|c|c|}
\hline GROUP-pre & $\mathbf{N}$ & Mean & Std. Dev & t & df & Sig. \\
\hline R-group & 42 & 43.10 & 18.892 & .180 & 82 & .857 \\
\hline E-group & 42 & 42.33 & 19.789 & & & \\
\hline
\end{tabular}

TABLE III.

COMPARE BETWEEN THE MEAN FOR E-GROUP PRE-TEST AND E-GROUP POST-TEST

\begin{tabular}{|l|c|c|c|c|c|c|}
\hline & Mean & $\mathbf{N}$ & Std. Deviation & t & df & Sig. \\
\hline E-group-pre-test & 42.33 & 42 & 19.789 & -17.166 & 41 & .000 \\
\hline E-group-post-test & 92.62 & 42 & 6.450 & & & \\
\hline
\end{tabular}

TABLE IV

SIGNIFICANT DIFFERENCE BETWEEN THE ACHIEVMENTS OF THE EXPERMINTAL GROUP REGULAR GROUP

\begin{tabular}{|l|c|c|c|c|c|c|}
\hline GROUP-post & N & Mean & Std. Devi & t & df & Sig. \\
\hline R-group & 42 & 88.45 & 8.146 & -2.599 & 82 & .011 \\
\hline E-group & 42 & 92.62 & 6.450 & & & \\
\hline
\end{tabular}

\section{REFERENCES}

[1] Dutta, S., \& Bilbao-Osorio, B. (2012). Global information technology report 2012. Living in a hyper connected world. Retrieved from: http://www3.weforum.org/docs/Global IT Report 2012. pdf.

[2] Wells, J., \& Lewis, L. (2006). Internet access in U.S. public schools and classrooms: 1994-2005.

[3] Pope, S. \& Kerris, N. (2010). iPad Wi-Fi + 3G models available in US on April 30. Apple, 20 April. http://www.apple.com/pr/library/2010/04/20ipad.html .

[4] Arslan, B. (2003). Bilgisayar Destekli Eğitime Tabi Tutulan Ortaöğretim Öğrencileriyle Bu Süreçte Eğitici Olarak Rol Alan Öğretmenlerin BDE'e İlişkin Görüşleri. The Turkish Online Journal of Educational Technology, 2 (4), 67-75.

[5] Fister, K. R. \& McCarthy, M. L. (2008). Mathematics Instruction and the Tablet PC. International Journal of Mathematical Education in Science and Technology. 39(3),285-292. http://dx.doi.org/10.1080/00207390701690303

[6] BBC Active, iPads in the Classroom (2010). retrieved in 11-222014. 2010 Educational Publishers LLP trading as BBC Active. http://www.bbcactive.com/BBCActiveIdeasandResources/iPadsint heClassroom.aspx. 
[7] King, I., \& Bass, D. (2013). Microsoft's Surface tablet Is said to fall short of predictions. Retrieved from http://www.bloomberg.com/news/2013-03-14/microsoft-s-surfacetablet-is-said-to-fall-short-ofpredictions.html,

[8] Alberta Education Cataloguing In Publication Data, (2012). iPads: what are we learning? : Summary report of provincial data gathering day, October 3, 2011. Copyright (C) Crown in Right of the Province of Alberta, as represented by the Minister of Education. ISBN 978-0-7785-9859-6 (Print).

[9] Riddell. R., 2013. 17 ways iPads will be used in schools in 2013 , Education Dive's, http://www.educationdive.com/news/17-waysipads-will-be-used-in-schools-in-2013/99550.

[10] Banister, S. 2010. Integrating the iPod Touch in K-12 Education: Visions and Vices. Computers in the Schools: Interdisciplinary Journal of Practice, Theory, and Applied Research, Volume 27, Issue 2, 2010 pages $121-131$

[11] Sullivan, R., 2013. The Tablet Inscribed: Inclusive Writing Instruction With the iPad, College Teaching, 61(1), 1-2. http://dx.doi.org/10.1080/87567555.2012.700339

[12] Daniel Churchill, Bob Fox, and Mark King, "Study of Affordances of iPads and Teachers' Private Theories,"International Journal of Information and Education Technology vol. 2, no. 3, pp. 251-254, 2012http://dx.doi.org/10.7763/IJIET.2012.V2.122

[13] Heick,T.,2012. 40 iPad Apps For Science By Category, teach thought 2012. http://www.teachthought.com/apps-2/40-ipad-appsfor-science-by-category/.

[14] Aksu, H. H., 2014. An evaluation Into Th Views Of Candidate Mathematics Teachers Over "Tablet Computers" To Be Applied In Secondary Schools. The Turkish Online Journal of Educational Technology, 13(1), pp 47-55.

[15] Herlihy, D. (2011). iPads in Education: A Classroom Learning Tool or Hub? Special Education Technology Practice, Vol. 13 Issue $3, \mathrm{p} 15$

[16] Nash, L 2012, Exploring iPads for learning, Scan, 31(1), pp 6-13.

[17] Bloomsapps, 2014. The Apple Core. https://sites.google.com/site/bloomsapps/the-app-le-core/1st-grade

[18] Bloom BS. 1984. Taxonomy of educational objectives. Allyn and Bacon, Boston, MA

[19] Anderson, L.W., and Krathwohl D. (Eds.) (2001). A Taxonomy for Learning, Teaching and Assessing: a Revision of Bloom's Taxonomy of Educational Objectives. Longman, New York.

[20] Shorser, L. (1999). Bloom's Taxonomy Interpreted for Mathematics. Retrieved from http://www.math.toronto.edu/writing/ BloomsTaxonomy.pdf.

[21] Teach with your ipads, 2014. Blooms Taxonomy with Apps. https://teachwithyouripad.wikispaces.com/Blooms+Taxonomy+wi th+Apps.

[22] Choate, J., Kotsanas, G. and Dawson, P. 2014. Exploring tablet PC lectures: Lecturer experiences and student perceptions in biomedicine. Australasian Journal of Educational Technology, 30(2). 167-183.

[23] Ciampa, K. \& Gallagher, T, 2013, Getting in Touch: Use of Mobile Devices in the Elementary Classroom.Computers in the Schools: Interdisciplinary Journal of Practice, Theory, and Applied ResearchVolume 30, Issue 4, 2013, pages 309-328.
[24] Karsenti, T., \& Fievez, A. (2013). The iPad in education: uses, benefits, and challenges - A survey of6,057 students and 302 teachers in Quebec, Canada. Montreal, QC: CRIFPE.

[25] Amy Hutchison, Beth Beschorner \& Denise Schmidt-Crawford (2012). Exploring the Use of the iPad for Literacy Learning. The Reading Teacher, 66(1), 15-23. http://dx.doi.org/10.1002/ TRTR.01090

[26] Shelley Kinash, Jeffrey Brand and Trishita Mathew, 2012, Challenging mobile learning discourse through research: Student perceptions of Blackboard Mobile Learn and iPads. Australasian Journal of Educational Technology 2012, 28(4), 639-655.

[27] Sachs, L. \& Bull, P. (2012). Case Study: Using iPad2 for a Graduate Practicum Course. In P. Resta (Ed.), Proceedings of Society for Information Technology \& Teacher Education International Conference 2012 (pp. 3054-3059). Chesapeake, VA: AACE.

[28] Dalrymple, J., 2012. iPad improves Kindergartners literacy scores, The Loop Magazine, http://www.loopinsight.com/2012/02/17/ ipad-improves-kindergartners-literacy-scores/

[29] Mills, K.A. \& Levido, A. (2011). iPed: Pedagogy for Digital Text Production. The Reading Teacher: A Journal of Research-Based Classroom Practice, 65(1), 80-91.

[30] Derting, T. R., \& Cox, J. R. (2008). Using a tablet PC to enhance student engagement and learning in an introductory organic chemistry course. Journal of Chemical Education, 85(12), 1638-1643. http://dx.doi.org/10.1021/ed085p1638

[31] Warschauer, M. (2011). Tablet Computers in Education. Eventually Tablets will Facilitate more Personalized and Interactive Learning. Educational Technology Debate - Exploring Learning in Developing Countries.

[32] Bokhove, C., \& Drijvers, P. (2010). Digital tools for algebra education: Criteria and evaluation. International Journal of Computers for Mathematical Learning, 15(1), 45-62. http://dx.doi.org/10.1007/s10758-010-9162-x

[33] Cayton-Hodges, G.A., Feng, G., Pan, X., \& Vezzu, M. (2013). iPad task design for elementary math: End of year report to the CBAL initiative. Princeton, NJ: Educational Testing Service.

\section{AUTHOR}

Dr. Ibtesam F. Al-Mashaqbeh is Associate professor, Faculty of Information Technology, Dept. of Computer Science, Al al-Bayt University (AABU), Mafraq-Jordan. Al-Mashaqbeh primary teaching areas are related to the use of computer applications in teaching and online teaching process. She has over 10 years teaching experience at the university levels for graduate and undergraduate levels. Her research and writing focus on pedagogical use of computer tools, and integration of specific computer tools into actual classroom instruction to support meaningful learning (ibtesamirbid@yahoo.com).

Submitted 19 September 2015. Published as resubmitted by the author 28 January 2016. 